\title{
Molecular markers as a tool for population and evolutionary studies of stingless bees
}

\author{
Maria Cristina ARIAS ${ }^{\mathrm{a}}$, Rute Magalhães BRITOa ${ }^{\mathrm{a}}$, Flávio de Oliveira FrANCISCO ${ }^{\mathrm{a}}$, \\ Geraldo MORETTO $^{\mathrm{b}}$, Favízia Freitas DE OLIVEIRA ${ }^{\mathrm{c}}$, Daniela SILVESTRE ${ }^{\mathrm{a}}$, Walter \\ Steven SHEPPARD ${ }^{\mathrm{d}}$ \\ a Departamento de Genética e Biologia Evolutiva, Instituto de Biociências, USP, São Paulo, SP, 05508-900, \\ Brasil \\ b Departamento de Ciências Naturais, Centro de Ciências Exatas e Naturais, FURB, Blumenau, SC, 89010-971, \\ Brasil \\ ${ }^{\mathrm{c}}$ Laboratório de Sistemática de Insetos (LASIS), Departamento de Ciências Biológicas, Universidade Estadual \\ de Feira de Santana, BR 116, km 3, 44031-460, Feira de Santana, BA, Brasil \\ ${ }^{d}$ Department of Entomology, Washington State University, Pullman, WA 99164-6382, USA
}

Received 30 November 2005 - revised 13 February 2006 - accepted 15 February 2006

\begin{abstract}
Molecular markers are widely used in biology to address questions related to ecology, genetics and evolution. In bees, molecular studies addressing those issues have focused on Apis and Apis mellifera. Here we describe examples where molecular markers from mtDNA and microsatellite analyses were applied to stingless bees species. The data obtained, although in some cases preliminary, have already proven useful to infer hypotheses about phylogeny, population dynamics, species validity and the evolution of this group of bees.
\end{abstract}

stingless bees / molecular marker / mitochondrial DNA / microsatellite / evolution / Apidae / Meliponini

\section{INTRODUCTION}

The development of molecular markers is directly related to advances in the field of molecular biology. The recent characterization of genomes, completely or partially, and knowledge of the molecular basis of genetic variation have been very important sources for the development of markers and establishment of evolutionary models at the inter and intraspecific levels (Li, 1997).

In the past decades numerous molecular markers have been characterized. Most of these are derived from sequence differences within mitochondrial DNA (mtDNA) and microsatellite loci. These molecular markers have been applied in studies of a great va-

Corresponding author: M.C. Arias, mcarias@ib.usp.br riety of organisms, and the resulting data have successfully added new, and sometimes striking information about species biology, ecology, behavior, population dynamics and evolution.

\section{MT DNA}

Animal mtDNA is a circular molecule (there are few exceptions) composed of about 37 genes coding for 13 proteins, 22 tRNAs, and two rRNAs. Also there is a non-coding region, the control region (or ' $\mathrm{A}+\mathrm{T}$ ' rich region), that is responsible for transcription and replication (Wolstenholme, 1992). Although, the genome content has been described as very conservative, the order in which the genes are organized in the mtDNA molecule is more variable than was initially predicted, 
especially for tRNA genes (Wolstenholme, 1992; Dowling et al., 1996). The mitochondrial genome is maternally inherited in most animals without recombination, so the whole set of genes is inherited as one unit (Avise, 1994). The mutation rate is high compared to single copy nuclear genes. However within the molecule there are genes or regions with higher and lower base substitution rates (Vawter and Brown, 1986; Brown, 1983). Therefore it is possible to select an appropriate region for analysis according to the taxonomic level under study.

\section{MICROSATELLITES}

Microsatellites are tandem sequence repeats of motifs with 1-6 bases (Hancock, 1999) randomly distributed along the euchromatic regions (Schlötterer and Wiehe, 1999). Microsatellite loci are considered codominant, selectively neutral, highly polymorphic, and show Mendelian inheritance (Moritz and Hillis, 1996). Due to these characteristics they have been extremely useful in analyses of relatedness, parentage, intraspecific variation, species hybridization, population dynamics, gene mapping and phylogeographic studies (Moritz and Hillis, 1996; Chakraborty and Kimmel, 1999). Microsatellites have been used also to evaluate the impact of reproductive behavior, social structure, and dispersion in endangered populations (Beaumont and Bruford, 1999). At the population level, the high polymorphism of microsatellites is considered a consequence of new mutations, genetic drift, and selection in genes closely linked to the repetitive sequences (Schlötterer and Wiehe, 1999).

Within the bee family Apidae much of the work using the above markers has been restricted to the genus Apis. A number of these studies have addressed questions about biogeography (Franck et al., 1998), population dynamics (Estoup et al., 1995), and the processes of hybridization and Africanization (Franck et al., 2001). Phylogenetic relationships have been reported based mainly on mtDNA sequencing (Garnery et al., 1992; Arias and Sheppard, 1996, 2005). The species
Apis mellifera was the first member of the Apidae to have its mtDNA completely sequenced (Crozier and Crozier, 1993) and most microsatellite loci known within Apidae have been described from this species (Estoup et al., 1993).

\section{STINGLESS BEES}

According to Michener (2000) the subfamily Apinae is composed of 19 tribes, including Apini, Meliponini, Euglossini and Bombini, the "corbiculate" bees. Apini and Meliponini are the only two tribes that contain species displaying a high level of social behavior. However while Apini is a monogenus tribe, comprising 11 valid species, Meliponini presents several genera. The total number of species within the Meliponini is still controversial, but is estimated to be about 400 (Michener, 2000). In contrast to the Apini, which has an endemic geographic distribution restricted to the Old World, the Meliponini has a very wide distribution and is found throughout the tropical areas of the World. The neotropical region has the highest number of species and has been indicated as the center of origin and dispersal of the stingless bees (Camargo and Pedro, 1992).

Although the Meliponini performs a very important ecological role as pollinators in several ecosystems, this group of bees is poorly studied in comparison to the Apini. The center of origin and dispersal routes responsible for current geographic distributions and local species richness remain controversial (Michener, 1979; Wille, 1983), as do the phylogenetic relationships within the tribe (Camargo and Pedro, 1992). Another intriguing question is related to the evolution of social behavior in the subfamily Apinae. While eusociality occurs in all species of the Apini and Meliponini, the question remains as to the number of times eusociality arose independently within the subfamily (Winston and Michener, 1977; Cameron, 1993; Schultz et al., 1999; Cameron and Mardulyn, 2001). Other aspects related exclusively to species or population level questions within the Meliponines, including speciation events, migration, gene flow mediated by 
males and/or females, genetic diversity and inbreeding, among others, are just beginning to be approached.

In the past few years research groups have shown special interest in applying molecular markers to address biological questions in Meliponini. Here we focus in reporting data from our research group and others addressing biological questions relevant to the Meliponini and for comparison, cite the literature from Apini.

\section{STINGLESS BEE MTDNA CHARACTERISTICS AND RESTRICTION MAPS}

Most of the studies of mtDNA characterization involve restriction enzyme digestion and restriction site mapping. To date, 16 Meliponini species have had their mitochondrial genome characterized, including a description of the main gene order: 5 from the genus Plebeia (Francisco et al., 2001), 7 from Melipona (Weinlich et al., 2004), two from Partamona (Brito and Arias, 2005), one from Tetragonisca and Schwarziana quadripunctata (presented here) (Fig. 1). The restriction maps for all these species were built by using 17 restriction enzymes and visualized by Southern blotting. In some, PCR+RFLP methodology was adopted to better localize neighbouring restriction sites. By PCR amplification of known regions based on the Apis mellifera mitochondrial genome (Crozier and Crozier, 1993) the position of restriction sites within the main mitochondrial genes were placed. Comparing the 16 restriction maps it is possible to verify restriction sites that are conserved among all species; for instance Pst I at $16 \mathrm{~S}$ gene, Cla I at CytB, others that are conserved within a genus and others that seem to be species specific. The conserved and variable sites are located in accordance with reported mitochondrial regions under severe or less severe functional constraints (Simon et al., 1994), respectively.

The total size of the Meliponini mitochondrial genome has been estimated to be $18500 \mathrm{bp}$, approximately $2200 \mathrm{bp}$ larger than in Apis mellifera (Francisco et al., 2001). This size difference seems to reside mainly in the $\mathrm{A}+\mathrm{T}$ rich region (control region), probably due to a large insertion. Compared to Apis mellifera, amplification of mtDNA fragments from other regions also yielded different sizes than expected. Some of these regions were sequenced, and several molecular events, including tRNA transpositions, insertions and deletions were verified (Silvestre, 2002; Silvestre et al., 2002). One of the most surprising findings was the absence of the intergenic region between the COI and COII genes in all 16 Meliponini species studied, verified by PCR and sequencing (see below). In Apis mellifera this intergenic region was first described by Crozier et al. (1989). Later several authors verified a high level of length and restriction pattern polymorphism, which, in some cases, was reliably correlated to evolutionary lineages previously postulated based on morphology (Garnery et al., 1992, 1995; Franck et al., 1998). Based on the secondary structure of the intergenic region, Cornuet et al. (1991) suggested that it might act as an extra mtDNA origin of replication. The absence of this region in Meliponini indicates that it may be an evolutionary feature intrinsic to A. mellifera. In fact, Cornuet and Garnery (1991) found a short intergenic region in A. cerana, A. dorsata and $A$. florea, resulted from a duplication of tRNA ${ }^{\text {leu }}$ gene and further regression or short elongation of this sequence, while in A. mellifera this region underwent multiple duplications.

\section{MTDNA AND PHYLOGENETIC INFERENCES}

Characterization of mtDNA by restriction enzymes provides useful information, including total genome size, restriction site number and relative site positions in a map and (in comparisons among taxa) this information may help solve systematic and phylogenetic questions (Avise, 1994; Hillis et al., 1996). In Apis, some studies have applied this methodology to infer phylogeny (Smith, 1991; Sihanuntavong et al., 1999).

In Meliponini a matrix of presence or absence of restriction sites at a determined position for the 16 species mentioned above was 


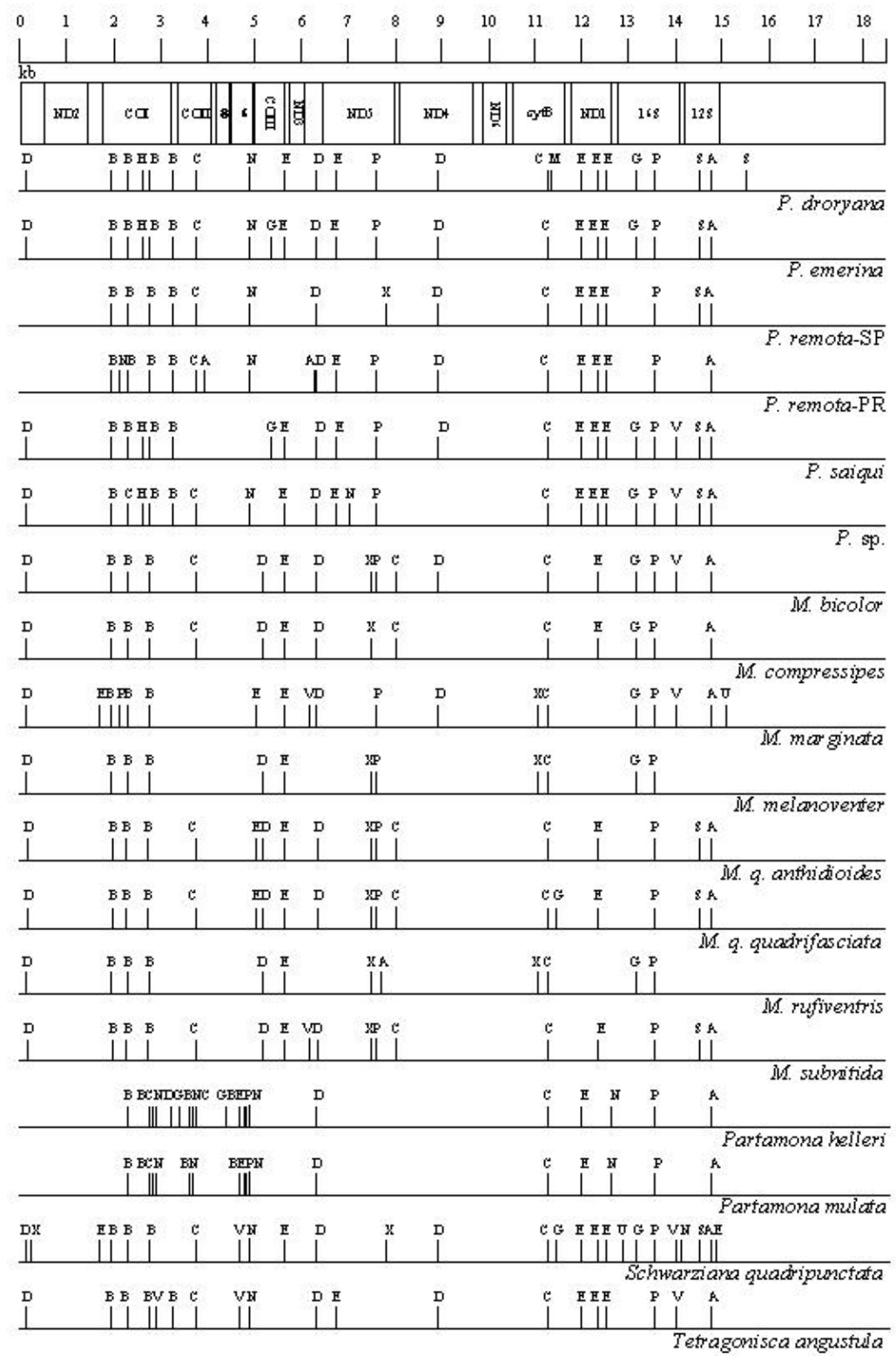

Figure 1. Linear restriction site maps of the mtDNA from 16 Meliponini species. Apis mellifera mtDNA gene order is used as a guide for the main genes in Meliponini maps. The A+T rich region and tRNAs were not represented. A, Hae III; B, $B c l$ I; C, Cla I; D, Hind III; E, EcoR I; G, $B g l$ II; H, Xho I; M, Bam HI; N, Nde I; P, Pst I.; S, Sca I; V, EcoR V; X, Xba I. ND2, NADH dehydrogenase subunit 2; COI, cytochrome c oxidase subunit 1 ; COII, cytochrome $\mathrm{c}$ oxidase subunit $2 ; 8$, ATP $\mathrm{F}_{0}$ synthase subunit $8 ; 6, \mathrm{ATP} \mathrm{F}_{0}$ synthase subunit 6; COIII, cytochrome c oxidase subunit 3; ND3, NADH dehydrogenase subunit 3; ND5, NADH dehydrogenase subunit 5; ND4, NADH dehydrogenase subunit 4; ND6, NADH dehydrogenase subunit 6; cytB, cytochrome B; ND1, NADH dehydrogenase subunit 1; 16S, large subunit ribosomal RNA; 12S, small subunit ribosomal RNA. 

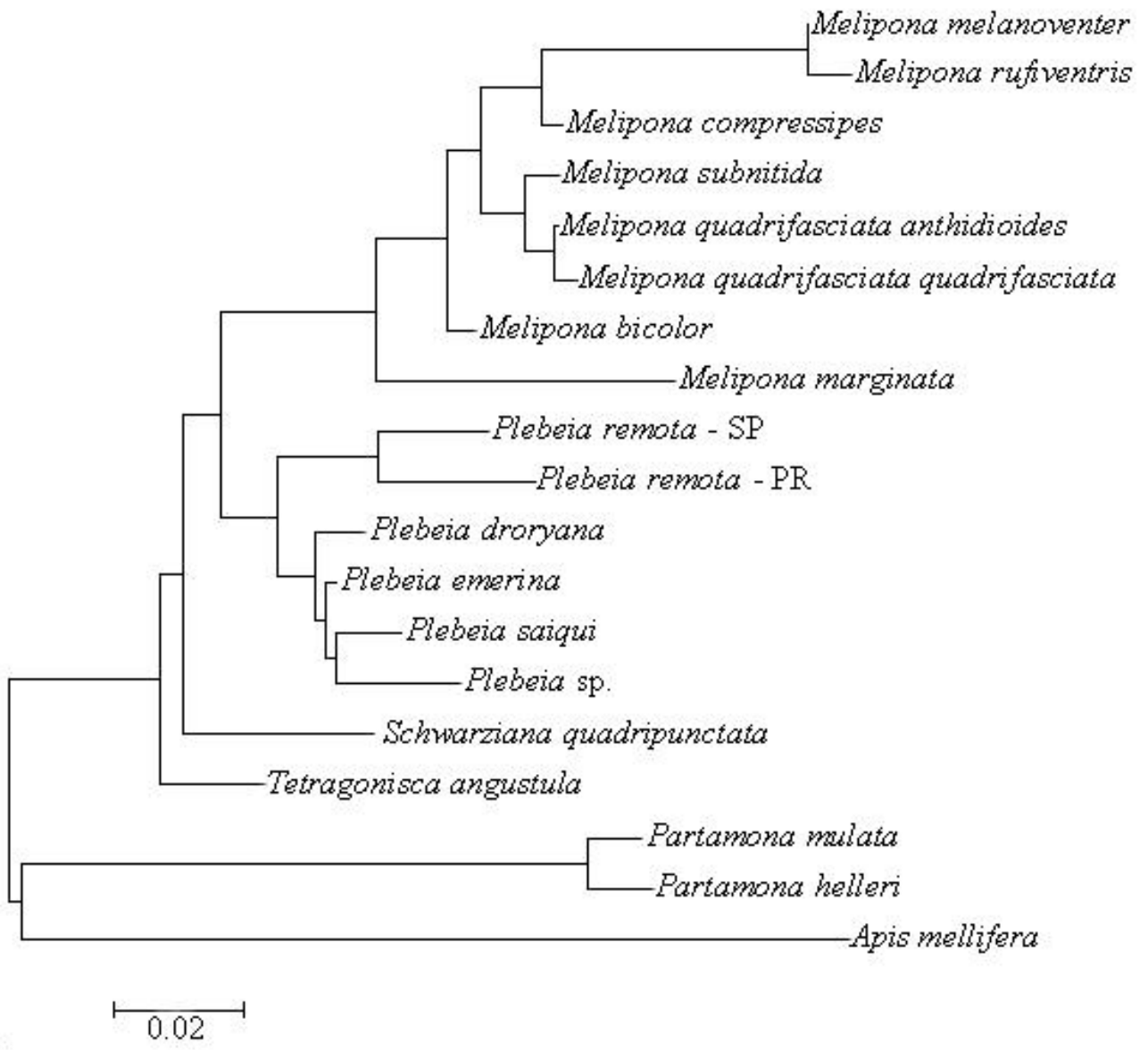

Figure 2. Unrooted phylogenetic tree generated by the Neighbor-joining method, based on RFLP data.

built, and submitted to phylogenetic analysis. Apis mellifera was used as outgroup. Figure 2 shows a phylogenetic tree obtained by neighbor joining. The genera Plebeia and Melipona were both monophyletic. The relationships within the Melipona clade showed a small genetic distance between Melipona quadrifasciata subspecies, as expected. Melipona marginata was positioned as the sister group. In fact, based on morphological traits of the genitalia, $M$. marginata is considered the most basal species in this genus (Rêgo, 1992). The phylogenetic relationships within the Plebeia clade placed the two samples from $P$. remota collected in two different localities together, as expected. However their genetic distance was higher than the observed be- tween some pairs of species (e.g. P. saiqui and $P$. emerina). The relationship between the two $P$. remota samples will be further discussed in the next section. The two species of Partamona also showed monophyly and Schwarziana quadripunctata and Tetragonisca angustula were sister groups to Melipona and Plebeia clades. A similar tree topology was obtained by UPGMA, differing just in the positions of Schwarziana quadripunctata and Tetragonisca angustula. UPGMA placed these two species as the sole sister group of the Plebeia clade. The results are certainly preliminary, if one considers that there are more than 30 and 40 species in the Plebeia and Melipona genera, respectively. Nonetheless the use of RFLP data and restriction mapping enabled 
the verification of monophyletic groups and basal species. The resolution within and between genera was satisfactory, suggesting that this methodology may be useful in future studies as more mtDNA restriction maps from other species are obtained.

Fernandes-Salomão et al. (2002) also used the same methodology to characterize the mtDNA and the nuclear ITS region for 16 Melipona species. Restriction sites were determined and a positive correlation between species groups determined by polymorphic restriction sites and published karyotype data was obtained. Later Fernandes-Salomão et al. (2005) sequenced the ITS region from 8 Melipona species and inferred phylogenetic relationships.

Franck et al. (2004) analyzed CytB gene sequences and inferred phylogenetic relationships for Trigona species from Australia and the Indo-Pacific region. The authors verified, among other findings, that $T$. hockingsi from northern and southern Queensland were highly genetically divergent. Microsatellite analysis clustered the samples from these two regions into separate groups, showing paraphyly. Due to their geographic distance and paraphyletic relationship, the authors inferred that these two populations are likely composed of distinct species.

MtDNA analyses, even by RFLP or sequencing, have contributed in a significant manner to solve phylogenetic questions in a number of species. In the genus Apis mtDNA analysis has increased significantly our understanding of phylogeny and evolution of species and the phylogeography of subspecies (Garnery et al., 1991; Arias and Sheppard, 1996, 2005; Arias et al., 1996; De La Rúa et al., 1998; Smith et al., 2000; Tanaka et al., 2001; Sheppard and Meixner, 2003; just to mention some).

\section{GENETIC VARIABILITY AT INTRA AND INTERSPECIFIC LEVELS}

Normally, mtDNA analysis in population studies begins with digestion by restriction enzymes. The number of restriction sites de- tected and their relative position on a restriction map are used to determine the mitochondrial haplotype (Avise, 1994).

Moretto and Arias (2005) characterized the mtDNA from the subspecies Melipona quadrifasciata quadrifasciata and M. q. anthidioides. In this study specific mtDNA regions were amplified through PCR and further digested with restriction enzymes. Polymorphic restriction sites were detected that showed differences between the two subspecies, especially for 4-base cutter enzymes. Later, Torres et al. (unpublished data) detected three more polymorphic sites using 4-base cutter enzymes, increasing the mitochondrial genome regions screened and restriction enzymes tested. This first baseline of knowledge of restriction site variability made possible population level screening for $M$. q. quadrifasciata. Initially twenty nine colonies were collected from three localities in Southern Brazil: Blumenau, Mafra (both SC) and Prudentópolis (PR) (Fig. 3), and analyzed through amplification of seven mitochondrial fragments and digestion with 15 restriction enzymes. Five haplotypes were identified: two exclusive to the samples from Prudentópolis, two were shared among samples from Mafra and Blumenau, and the fifth one was found in only one colony from Blumenau (Torres et al., unpublished data). The samples from Blumenau and Mafra were homogenous, and may be considered as one population at the mtDNA level. Inclusion of more population samples and analysis with other molecular markers such as microsatellite in future studies will improve our comprehension about the population dynamics and the natural barriers involved in this scenario.

A population survey was also conducted for the species Plebeia remota (Francisco, 2002). Fifty-four colonies were sampled from 2 localities: Cunha (SP) (18 nests) and Prudentópolis (PR) (33 nests) (Fig. 3). Eight mitochondrial haplotypes were verified by using 15 restriction enzymes. Both populations had four exclusive haplotypes and statistical analyses showed isolation between the two populations. High values of genetic distance were found $\left(F_{S T}=0.686 ; \delta=0.386, \delta\right.$ means nucleotide divergence between all pairs of populations), suggesting that bees from Prudentópolis and 


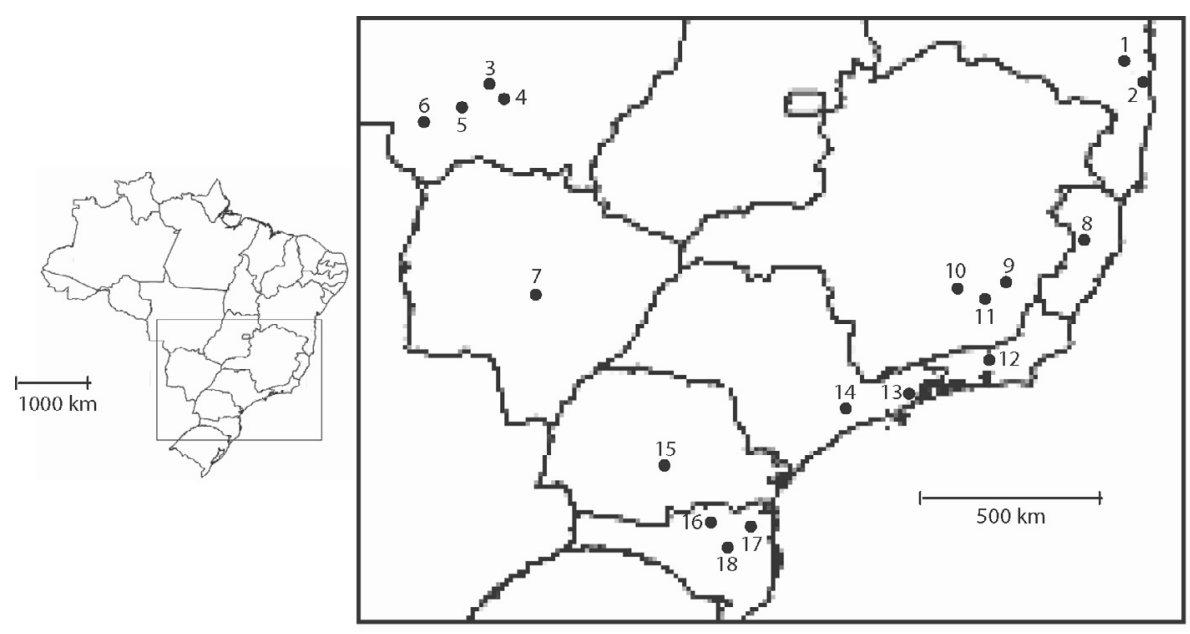

Figure 3. Map of Brazil and in detail the geographic origin of the samples are pointed out. Following are the local names according to the numbers in the map and the species collected in each site:
1. Coaraci (BA)
7. Campo Grande (MS)
2. Ilhéus (BA)
8. Colatina (ES)
3. Cuiabá (MT)
9. São Miguel do Anta (MG)
4. Santo Antônio do Leverger (MT)
10. Porto Firme (MG)
5. Poconé (MT)
11. Viçosa (MG)
6. Cáceres (MT)
12. Petrópolis (RJ)

13. Cunha (SP)

14. São Paulo (SP)

15. Prudentópolis (PR)

16. Mafra (SC)

17. Luiz Alves (SC)

18. Blumenau (SC)

Plebeia remota (13-15); Partamona mulata (3-7); Partamona helleri (1, 2, 8-11, 13, 14, 17, 18); Melipona bicolor $(11,12)$ and Melipona quadrifasciata $(15,16,18)$.

Cunha may represent independent evolutionary units. These data corroborate the phylogenetic relationship and genetic distance we observed between $P$. remota from these two localities (Fig. 2). Microsatellite data were also used to assay the genetic variability of these two populations. Seven primers pairs derived from Melipona bicolor (5) and Scaptotrigona postica (2) were utilized. The results revealed considerable isolation of the populations $(P<$ 0.0001 ; chord distance $=0.239$ ), which is in agreement with mtDNA data (Francisco, 2002).

Considering the data obtained for Plebeia remota and Melipona quadrifasciata, it is worthwhile to point out that samples collected in Prudentópolis were always distinct from the others. The ecological characteristic that can be correlated to this distinctness is that Prudentópolis is located in a conifer forest biome, while the other localities are in Atlantic rain forest remains. Paleogeographic and paleoclimatic events may be responsible for this scenario, indicating isolation of species since those events have occurred. Further investigations should be developed, including other genera and species, to examine this hypothesis.

Brito (2005) studied populations of two Partamona species: P. mulata, which were distributed in southern Mato Grosso and northern Mato Grosso do Sul states (savanna habitat) and $P$. helleri which has a wider geographic distribution from Santa Catarina to southern Bahia state (Atlantic rain forest habitat). This study employed PCR+RFLP of mtDNA and analysis of 9-10 microsatellite loci. P. mulata was collected from 58 nests in 5 localities within its natural range (Fig. 3). Only two mitochondrial haplotypes were detected among the colonies screened, and the presence/absence of a single restriction site differentiated the haplotypes. Statistical analyses indicated no differentiation among the 5 populations $\left(F_{S T}=0.000 ; \delta=0.006\right)$, suggesting that the species could have passed through a 
recent population bottleneck. Conversely, ten haplotypes were observed in 47 colonies of $P$. helleri collected from 10 distinct sites (Fig. 3). Some haplotypes were exclusive to and others were shared among populations. Statistical analysis showed population differentiation $\left(F_{S T}=0.317 ; \delta=0.012\right)$ and the observed phylogeographic distribution suggested a possible recent isolation probably due Atlantic Forest fragmentation during the Pleistocene. Microsatellite analysis showed low levels of genetic variability in both species and moderate population structuring $\left(F_{S T}=0.085\right.$ in P. mulata; $F_{S T}=0.349$ in $P$. helleri), unrelated to the geographic distribution. This might be a consequence of male migration, since the queens are highly philopatric (Wille and Orozco, 1975) or recent isolation due to habitat fragmentation.

Although in the above examples morphometric analysis was not applied, this is still a critical tool in the systematics of this group. An excellent example of this comes from a recent study where molecular data were very important to detect cryptic speciation in Melipona bicolor that was supported by subsequent morphological analysis (de Oliveira et al., unpublished data). Melipona bicolor has been traditionally divided into two or three subspecies based on color, including $M$. bicolor bicolor Lepeletier, 1836 (reddish form) and M. bicolor schenki Gribodo, 1893 (black form). The geographic distribution of these forms is not well-resolved, but the reddish form seems more populous in the northern portion of its range (including the states of SP, RJ, $\mathrm{MG}$, and $\mathrm{BA}$ ), while the black form predominates in southern Brazil (RS, SC, and PR). It is common for colonies of this bee to be shipped within the private trade. The possible effect of human-assisted transport cannot be fully assessed without some basic knowledge of natural patterns of distribution and a better understanding of the genetic relationships among the putative subspecies or "forms" of this bee. Samples from 37 colonies were collected (Fig. 3) from a number of Brazilian states and ecological zones representing much of its known range. Some of the collections were made from private beekeepers and some were from wild collected stocks now in re- search or beekeeper meliponaries. The method of PCR+RFLP of mtDNA was applied and it was possible to detect and resolve two mtDNA region-restriction enzyme specific marker systems. The marker frequency difference between subspecies was pronounced. Preliminary analysis showed differences between the subspecies where $M$. b. bicolor was polymorphic for haplotype patterns a and c, while $M$. $b$. schenki appeared to be fixed for pattern $\mathrm{b}$. This prompted a careful study of morphological characters within the different samples and full analysis using cladistic methods. When 11 morphological characters were scored for 22 colonies representing the two subspecies, no set of worker based differences was able to separate the two taxa. However, fixed differences were found in several characters related to the male genitalia. It appears that populations previously considered to be subspecies will be raised to species status (unpublished data). Further, the mtDNA markers developed have been shown to be useful in population level analyses of M. bicolor. Additional screening of Melipona bicolor populations, including a previously suggested third subspecies, M. bicolor ssp. (gray form), will permit researchers to better understand the phylogeography and current distribution patterns of this important native pollinator.

The combination of different methods to assay populations is very common and desirable. In Apis mellifera and Apis cerana, population studies have been developed using both mtDNA and microsatellite analysis and have increased our comprehension about subspecies population dynamics, biogeography, introgression, and evolution (Franck et al., 1998, 2000a, b; Segura, 2000; Sheppard and Smith, 2000; De la Rúa et al., 2001, 2002, 2003; Paar et al., 2004; Sušnik et al., 2004). Similarly, morphometric analysis combined with molecular data has been applied to study intogression in honey bees (Meixner et al., 1993, 2000).

\section{INTRACOLONIAL GENETICS}

An intriguing question in social insects has been the reproductive conflict between queens and workers. The queen mating frequency 
greatly influences the kin structure and the relatedness among workers (Crozier and Pamilo, 1996). In honey bees it is well known that the queen mates with several to many males (polyandry) and drone egg production in a colony is basically attributed to the queen (Ratnieks, 1993). To study reproductive conflicts, policing behavior, mate frequency and patriline number, researchers have been employed microsatellite loci analysis. Châline et al. (2002) described an anarchistic honey bee colony in which the workers produced males even in the presence of the queen. This kind of anarchistic behavior had been previously detected by Oldroyd et al. (1994) in a single Australian colony.

Contrary to Apini, Meliponini is believed to be monondrous in a general sense (Kerr et al., 1962). Recently, several species have been studied and insights about male production, kin selection, queen mate frequency and social conflicts have been reported (Peters et al., 1999; Paxton, 2000; Green and Oldroyd, 2002; Tóth et al., 2002a, b, 2003, 2004; Paxton et al., 2003). However, this research would not be possible without the preliminary work of genomic library development and microsatellite screening for Meliponini species. A set of primers derived from Melipona bicolor, Scaptotrigona postica and Trigona carbonaria is available for such studies (Peters et al., 1998; Paxton et al., 1999; Green et al., 2001).

A set of species-specific microsatellite primers was also developed for Apis mellifera and Bombus terrestris (Estoup et al., 1993, 1995). Although Bombus belongs to the tribe Bombini and is not the focus of this review, it worth noting that studies at intracolony and population levels have been successfully accomplished in this genus (Estoup et al., 1996; Shao et al., 2004).

\section{MITOCHONDRIAL GENOME EVOLUTION}

The mitochondrion seems to have a single origin in eukaryotes; such a view is supported by the fact that mitochondrial gene content is highly conserved among species. This fact could hardly be explained by convergence
(Boore and Brown, 1998). Another important feature is gene order, the placement of genes on the mitochondrial molecule is also well conserved. Rearrangements are rare and the order is considered stable among closely related organisms (Brown, 1983).

The mitochondrial genome of Apis mellifera was sequenced more than a decade ago (Crozier and Crozier, 1993) and the arrangement of the main genes (protein-coding and rRNA genes) was extremely conserved when compared with Drosophila. However, 8 tRNA genes were in different positions or translocated. In fact, tRNA genes are known to be involved in mtDNA rearrangements (Curole and Kocher, 1999). They are distributed in eleven clusters, each one positioned between two protein-coding (or rRNA) genes. For functional reasons, some of these clusters are more conserved than others, like the 11th cluster, that always contains a tRNA ${ }^{\text {Val }}$ between the genes $16 \mathrm{~S}$ and $12 \mathrm{~S}$. Other clusters have proven to be more susceptible to recombination (Boore, 1999), such as the 1st and the 6th clusters (control region-ND2 and ND3-ND5 junctions, respectively).

PCR-detected size differences between Apis mellifera and Meliponini mtDNA and the need to better understand Meliponine mtDNA for primer design led to the initiation of a sequencing project for Melipona bicolor mtDNA (Silvestre, 2002). Nearly 15000 bp (of the total mtDNA genome of $18500 \mathrm{bp}$ ) were sequenced and annotated (GenBank accession number AF466146). Characteristics such as protein chemical properties, codon usage, $\mathrm{A}+\mathrm{T}$ content, gene size, tRNA secondary structure, and gene order were analyzed. The absence of an intergenic region between COI-COII genes, observed indirectly by $\mathrm{PCR}$, was confirmed by sequencing. The A+T bias was very high in $M$. bicolor mtDNA. In fact, it was higher than in Apis mellifera, the insect that had been previously cited to have the highest AT bias (Simon et al., 1994). Even excluding the $\mathrm{A}+\mathrm{T}$-rich region (control region) of A. mellifera, the AT composition was higher in the $M$. bicolor mitochondrial genome compared to A. mellifera $(86.7 \%$ and $84.3 \%$, respectively). 


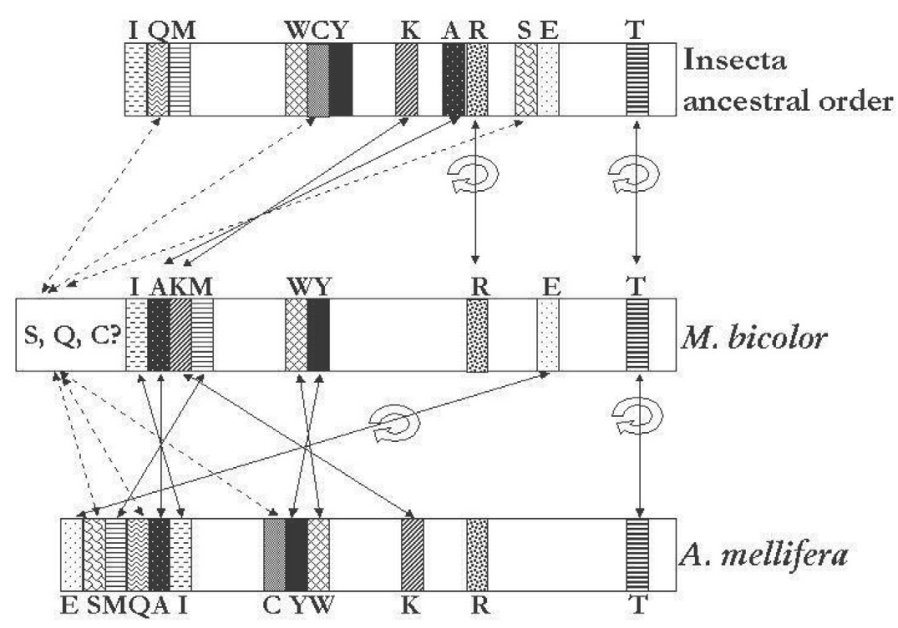

Figure 4. Schematic representation of mitochondrial tRNA gene rearrangements between Apis mellifera (Crozier and Crozier, 1993) and Melipona bicolor (Silvestre, 2002). Only tRNA genes presenting different gene order are represented. The putative ancestral gene order of Insecta (Boore, 1999) is also represented here for comparison. Each gene is identified by the letters of the universal code of the amino acid carried by the corresponding tRNA. The thin solid arrows indicate translocations and the thick circular arrows are symbols of strand inversions. The dotted arrows indicate the possible positions for those tRNA genes not present in the sequenced portion of M. bicolor genome (figure from Silvestre and Arias, 2006).

The protein coding genes of $M$. bicolor have the same gene order as Apis mellifera. However, when comparing tRNA gene order, eleven translocations were found or inferred to be located in different positions or on a different strand (Silvestre and Arias, 2006) (Fig. 4). The number of genes involved in the rearrangements between these two bee tribes of the subfamily Apinae was much higher than that usually found between pairs of families of Diptera (http://www.jgi.doe.gov/programs/comparative/ MGA_Source_Guide.html). Hymenoptera seem to have an accelerated rate of mtDNA gene rearrangements in comparison to other Insecta orders. Dowton et al. (2002) found several gene order differences among wasps belonging to the family Braconidae. The molecular mechanisms responsible for these rearrangements have been described (Cantatore et al., 1987; Levinson and Gutman, 1987; Macey et al., 1997; Dowton and Austin, 1999), but their higher incidence in bees and wasps remains an open research field.

The analysis of gene order has been pointed out to be a possible source of characters to reconstruct phylogenetic relationship (Boore and Brown, 1998). The great number of potential arrangements makes convergence very unlikely and homology more plausible. The gene arrangements are considered selectively neutral (Boore and Brown, 1998). The differences in the tRNA gene order we found can be seem as promising molecular tool to study evolutionary and phylogenetic questions of bees and especially the origin of social behavior. The question of the number of independent origins of social behavior in the family Apidae has been addressed by several researchers. These involved traditional approaches like morphology (Winston and Michener, 1977; Engel, 2001), behavior and also DNA sequence data (Koulianos et al., 1999; Schultz et al., 1999; Lockhart and Cameron, 2001).

The fact that the Apini and Meliponini have a different tRNA gene order deserves further investigation for insights about single or multiple origins of eusociality. We are now investigating the mtDNA gene order of other bee tribes, including the "corbiculate" Bombini (primitively eusocial) and Euglossini (from solitary to primitively eusocial), Eucerini, Tetrapediini, Ericrocidini, Centridini, Anthophorini, Rhathymini, Tapinotaspidini, 
Emphorini (classification according Michener, 2000), and are including species of Xylocopinae, Halictidae and Megachilidae as outgroups. At present, there is some evidence of very conserved clusters of tRNA genes, and some clusters with gene order variations (Silvestre, unpublished data). The latter clusters are typically the ones that have been called "hot spots" (clusters of tRNAs showing high level of translocations) by Dowton and Austin (1999) and Dowton et al. (2003). Also a putative pseudogene was found in Bombini (Silvestre, unpublished data). In the future we hope that these data can contribute to the understanding of mtDNA molecular evolution and the evolution of social behavior in bees.

Although some of the examples cited here are preliminary or unpublished, they clearly show the potential of molecular markers to solve some important questions within the stingless bees. Interdisciplinary studies, that combine these molecular approaches with general ecology, behavior, biogeography and morphology, will contribute most significantly to our knowledge and comprehension of stingless bee biology, population dynamics and evolution.

\section{ACKNOWLEDGEMENTS}

We would like to express our thanks to Dra. Silvia Regina de Menezes Pedro (FFCLRP - USP), for the identification of Partamona specimens; Carlos Chociai, Sebastião Gonzaga (Associação Paranaense de Apicultores - APA), Claiton Antonio Kunzler, Dr. Geraldo Moretto (FURB), Sr. Gesimar Célio dos Santos, Dra. Isabel Alves dos Santos (IB-USP), Sr. Jean Carlos Locatelli, Dr. Lucio de Oliveira Campos and Sra. Sidia Witter for providing Meliponini samples; Rogélio Rodrigues Torres (Departamento de Zootecnia, Universidade Nacional de Bogotá, Colômbia) for collecting molecular data; Susy Coelho for her valuable technical support; and finally to FAPESP and CNPq for grants and student fellowships.

Résumé - Les marqueurs moléculaires comme outil pour étudier les populations et l'évolution des abeilles sans aiguillon. Un certain nombre de marqueurs moléculaires ont été décrits pour les abeilles et appliqués aux études portant sur la génétique des populations et l'évolution. Deux de ces marqueurs moléculaires se sont montrés particulièrement instructifs : les polymorphismes de l'ADN mitochondrial (ADNmt) et la variation des microsatellites. Au sein des apoïdes ces marqueurs ont surtout été utilisés chez le genre Apis pour étudier la dynamique des populations, la phylogéographie, la validité des espèces et la phylogenèse. Dans la sousfamille des Apinae, les Apini et les Meliponini sont les deux seules tribus comprenant des espèces avec un comportement social élevé. Contrairement aux Apini qui ont une répartition géographique naturelle dans l'Ancien Monde, les Meliponini se rencontrent dans toutes les régions tropicales. Plus de 400 espèces ont été décrites et l'on considère les Néotropiques comme le centre de leur origine et de leur dispersion. La capacité de ces marqueurs moléculaires à répondre aux questions de biologie et d'évolution au sein des Apini nous a encouragés à appliquer des méthodologies semblables aux Meliponini. Au début des cartes de restriction ont été construites pour 16 espèces et la position des sites de restriction dans les principaux gènes mitochondriaux a été déterminée (Fig. 1). La comparaison des 16 cartes de restriction a permis de vérifier les sites de restriction et de déterminer leur conservation. Parmi toutes les espèces testées, par exemple $P s t$ I sur le gène $16 \mathrm{~S}$, Cla I sur le gène CytB étaient conservés; d'autres ne l'étaient qu'au sein d'un genre, et d'autres apparaissaient très spécifiques d'une espèce. Une matrice basée sur les sites de restriction cartographiés a été construite et utilisée pour en déduire une relation phylogénétique entre ces espèces (Fig. 2). Bien que le nombre d'espèces étudiées soit faible par rapport à la grande diversité du groupe, nous avons montré la possibilité d'utiliser l'ADNmt pour déduire des relations phylogénétiques.

$\mathrm{Au}$ niveau des populations, nous avons testé le polymorphisme de l'ADNmt et la variation des microsatellites chez cinq espèces (Plebeia remota, Partamona mulata, Partamona helleri, Melipona quadrifasciata et Melipona bicolor) prélevées dans leurs régions endémiques (Fig. 3). Les données nous ont permis de répondre aux hypothèses relatives à la dynamique des populations y compris les flux de gènes, la migration et les évènements récents d'isolement et la spéciation. Dans certains cas une preuve de corrélation entre la structure des populations et la paléogéographie est apparue. A partir de la preuve moléculaire d'une structure intraspécifique au sein de Melipona bicolor, une analyse morphologique détaillée a été faite au sein d'un échantillonnage ayant une origine géographique variée. On a trouvé des différences constantes dans les genitalia mâles entre les groupes délimités par l'analyse moléculaire, ce qui a conduit à une révision taxonomique et à la description d'espèces.

Certaines régions d'ADNmt présentent des différences importantes entre Apis mellifera et 
les Meliponini. Pour Melipona bicolor environ 15000 pb (le génome de l'ADNmt en compte 18500 au total), ont été séquencés et annotés (GenBank accession number AF466146). Non seulement l'ADNmt de Melipona comprend environ 2200 bases de plus que celui d'Apis, mais il est encore plus riche en zones A+T que celui d'A. mellifera. La région intergénique entre les gènes COI et COII, si bien caractérisée et fortement polymorphe chez A. mellifera, est absente chez $M$. bicolor. La généralisation, selon laquelle l'ordre des gènes mitochondriaux est fortement conservé chez des organismes étroitement apparentés, ne s'applique pas à $A$. mellifera et $M$. bicolor. Onze translocations de gènes d'ARNt ont été vérifiées entre ces deux abeilles (Fig. 4). La fréquence élevée des réarrangements géniques entre ces deux espèces est maintenant en cours d'étude chez diverses espèces de la famille des Apidae. La comparaison de l'ordre des gènes de l'ADNmt peut être utile pour répondre aux questions sur l'origine et la dispersion des Meliponini et aussi sur l'origine de l'eusocialité chez les Apidae.

abeille sans aiguillon / marqueur moléculaire / ADNmt / microsatellite / évolution / Apidae / Meliponini

Zusammenfassung - Molekulare Marker als Werzeuge für Populations- und Evolutionsstudien an Stachellosen Bienen. Für populationsgenetische und evolutionsbiologische Studien an Bienen sind bereits eine Anzahl molekularer Marker vefügbar. Innerhalb dieser Marker erwiesen sich vor allem mitochondriale DNA (mtDNA) Polymorphismen und variable Mikrosatelliten als informativ. Innerhalb der Bienen wurden solche Marker vor allem in Studien zur Populationsdynamik, Phylogeographie, Artenvalidierung und Phylogenie bei der Gattung Apis eingesetzt. Innerhalb der Unterfamilie Apinae weisen nur die beiden Tribus Apini und Meliponini Arten mit hochsozialem Verhalten auf. Während sich bei Apini die natürliche geographische Verbreitung auf die Alte Welt beschränkt, sind die Meliponini in den gesamten Tropenregionen verbreitet. Über 400 Arten Stachelloser Bienen sind bereits beschrieben und die Neotropen gelten als das Ursprungs- und Verbreitungszentrum dieser Gruppe. Die Eignung molekularer Marker für Fragen zur Biologie und Evolution der Apini stimulierte uns, ähnliche Methoden auch bei den Meliponini einzusetzen. Zunächst erstellten wir Restriktionskarten für 16 Arten und bestimmten die Positionen der Restriktionsschnittstellen in den wichtigsten mitochondrialen Genen (Abb. 1). Der Vergleich der 16 Restriktionskarten erlaubte die Verifizierung der Schnittstellen und die Bestimmung ihre Konservierung. Bei allen untersuchten Arten waren zum Beispiel PstI im $16 \mathrm{~S}$ Gen und ClaI in
CytB konserviert, andere waren innerhalb der einzelnen Gattungen konserviert, und wieder andere variierten artspezifisch. Wir erstellten eine Matrix auf der Basis dieser Restriktionsschnittstellen und benutzten diese für Schlussfolgerungen über phylogenetische Beziehungen zwischen diesen Arten (Abb. 2). Obwohl die Zahl der untersuchten Arten relative gering ist, im Vergleich zur Diversitát dieser Gruppe, wurde das Potential von mtDNA-Studien für die Aufdeckung phylogenetischer Beziehungen deutlich.

Auf Populationsebene untersuchten wir 5 Arten (Plebeia remota, Partamona mulata, Partamona helleri, Melipona quadrifasciata und Melipona bicolor) hinsichtlich mtDNA Polymorphismen und Mikrosatelliten-Variationen. Diese Arten wurden in ihren jeweils endemischen Regionen gesammelt (Abb. 3). Die Daten ermöglichten es uns, Hypothesen zur Populationsdynamik aufzustellen, insbesondere zu Genfluss und rezenten Isolations- und Artbildungsereignissen. In einigen Fällen wurde eine Korrelation zwischen Populationsstruktur und Paläogeographie deutlich. Basierend auf molekularen Daten zur innerartlichen Struktur führten wir an Melipona bicolor eine morphologische Untersuchung an Individuen aus geographisch diversen Sammelpunkten durch. Wir fanden konstante Unterschiede in den männlichen Genitalien innerhalb der anhand molekularer Marker definierten Gruppen. Dies führte zur taxonomischen Revision und Artbeschreibung.

In einigen mtDNA-Regionen wiesen Apis mellifera und Meliponini substantielle Unterschiede auf. Für Melipona bicolor wurden etwa 15000 Basenpaare der mtDNA (das gesamte mtDNA-Genom besteht aus 18500 bp) sequenziert und annotiert (GenBank Zugangsnummer AF466146). Ausser der Tatsache, das das Melipona mtDNA-Genom um 2200 Basen grösser ist als das der Honigbiene, ist es sogar noch A+T-reicher als das von A. mellifera. Die Region zwischen den COI- und COII-Genen, die bei Apis mellifera besonders gut charakterisiert und stark polymorph ist, fehlt bei $M$. bicolor. Die allgemeine Ansicht, dass die Anordnung der mitochondrialen Gene zwischen nahverwandten Organismen hochkonserviert ist, trifft für A. mellifera und M. bicolor nicht zu. Wir fanden elf Translokationen für tRNAGene bei diesen beiden Bienenarten (Abb. 4). Die hohe Frequenz der Änderungen in der Genanordnung zwischen diesen beiden Arten stimulierte jetzt die Ausweitung solcher Untersuchungen auf andere Arten der Familie Apidae. Vergleiche zur Genanordnung in der mtDNA können auch nützlich sein, um Fragen nach dem Ursprung und der Verbreitung der Meliponinen, sowie dem Ursprung der Eusozialität innerhalb der Apidae nachzugehen.

molekulare Marker / mitochondriale DNA / Mikrosatelliten / Stachellose Bienen / Evolution / Apidae / Meliponini 


\section{REFERENCES}

Arias M.C., Sheppard W.S. (1996) Molecular phylogenetics of honey bee subspecies (Apis mellifera L.) inferred from mitochondrial DNA sequence, Mol. Phylogenet. Evol. 5, 557-566.

Arias M.C., Sheppard W.S. (2005) Phylogenetic relationships of honey bees (Hymenoptera: Apinae: Apini) inferred from nuclear and mitochondrial DNA sequence data, Mol. Phylogenet. Evol. 37, 25-35.

Arias M.C., Tingek S., Kelitu A., Sheppard W.S. (1996) Apis nuluensis (Tingek, Koeniger and Koeniger) and its relationships with sympatric species inferred from DNA sequences, Apidologie $27,415-422$.

Avise J.C. (1994) Molecular markers, natural history and evolution, Chapman and Hall, New York.

Beaumont M.A., Bruford, M.W. (1999) Microsatellites in conservation genetics, in: Goldstein D.B., Schlötterer C. (Eds.), Microsatellites: Evolution and applications, Oxford University Press, New York, pp. 165-182.

Boore J.L., Brown W.M. (1998) Big trees from little genomes: mitochondrial gene order as a phylogenetic tool, Curr. Opin. Genet. Dev. 8, 668-674.

Boore J.L. (1999) Animal mitochondrial genomes, Nucleic Acid Res. 27, 1767-1780.

Brito R.M. (2005) Análise molecular e populacional de Partamona mulata (Moure In Camargo, 1980) e Partamona helleri (Fiese, 1900) (Hymenoptera, Apidae, Meliponini), $\mathrm{PhD}$ thesis, Instituto de Biociências, Universidade de São Paulo, São Paulo, SP.

Brito R.M., Arias M.C. (2005) Mitochondrial DNA characterization of two Partamona species (Hymenoptera, Apidae, Meliponini) by PCR+RFLP and sequencing, Apidologie 36, 431-437.

Brown W.M. (1983) Evolution of animal mitochondrial DNA, in: Nei M., Koehn R.K. (Eds.), Evolution of genes and proteins, Sinauer Associates, Sunderland, MA, pp. 63-88.

Camargo J.M.F., Pedro S.R.M. (1992) Sytematics, phylogeny and biogeography of the Meliponinae (Hymenoptera, Apidae): a mini-review, Apidologie 23, 509-522.

Cameron S.A. (1993) Multiple origins of advanced eusociality in bees inferred from mitochondrial DNA sequences, Proc. Natl Acad. Sci. (USA) 90, 86878691.

Cameron S.A., Mardulyn P. (2001) Multiple molecular data sets suggest independent origins of highly eusocial behavior in bees (Hymenoptera: Apinae), Syst. Biol. 50, 194-214.

Cantatore P., Gadaleta M.N., Roberti M., Saccone C., Wilson A.C. (1987) Duplication and remoulding of tRNA genes during the evolutionary rearrange- ment of mitochondrial genomes, Nature 329, 853 855.

Chakraborty R., Kimmel M. (1999) Statistics of microsatellite loci: estimation of mutation rate and pattern of population expasion, in: Goldstein D.B., Schlötterer C. (Eds.), Microsatellites: Evolution and applications, Oxford University Press, New York, pp. 139-150.

Châline N., Ratnieks F.L.W., Burke T. (2002) Anarchy in the UK: detailed genetic analysis of worker reproduction in a naturally occurring British anarchistic honeybee, Apis mellifera, colony using DNA microsatellites, Mol. Ecol. 11, 1795-1803.

Cornuet J.-M., Garnery L. (1991) Mitochondrial DNA variability in honeybees and its phylogeographic implications, Apidologie 22, 627-642.

Cornuet J.-M., Garnery L., Solignac M. (1991) Putative origin and function of the intergenic region between COI and COII of Apis mellifera $\mathrm{L}$. mitochondrial DNA, Genetics 1128, 393-403.

Crozier R.H., Crozier Y.C. (1993) The mitochondrial genome of the honeybee Apis mellifera: complete sequence and the genome organization, Genetics $133,97-117$.

Crozier R.H., Pamilo P. (1996) Evolution of social insect colonies, Oxford University Press, Oxford.

Crozier R.H., Crozier Y.C., Mackinlay A.G. (1989) The CO-I and CO-II region of honeybee mitochondrial DNA: evidence for variation in insect mitochondrial evolutionary rates, Mol. Biol. Evol. 6, 399-411.

Curole J.P., Kocher T.D. (1999) Mitogenomics: digging deeper with complete mitochondrial genomes, Trends Ecol. Evol. 14, 394-398.

De la Rúa P., Serrano J., Galián J. (1998) Mitochondrial DNA variability in the Canary Islands honeybees (Apis mellifera L.), Mol. Ecol. 7, 1543-1547.

De la Rúa P., Galián J., Serrano J., Moritz R.F.A. (2001) Genetic structure and distinctness of Apis mellifera L. populations from the Canary Islands, Mol. Ecol. 10, 1733-1742.

De la Rúa P., Galián J., Serrano J., Moritz R.F.A. (2002) Microsatellite analysis of non-migratory colonies of Apis mellifera iberica from southeastern Spain, J. Zool. Syst. Evol. Res. 40, 164 168.

De la Rúa P., Galián J., Serrano J., Moritz R.F.A. (2003) Genetic structure of Balearic honeybee populations based on microsatellite polymorphism, Genet. Sel. Evol. 35, 339-350.

Dowling T.E., Moritz C., Palmer J.D., Rieseberg L.H. (1996) Chapter 8: Nucleic acids III: analysis of fragments and restriction sites, in: Hillis D.M., Moritz C., Mable B.K. (Eds.), Molecular Systematics, 2nd ed., Sinauer Associates, Massachusetts, pp. 249-320. 
Dowton M., Austin A.D. (1999) Evolutionary dynamics of a mitochondrial rearrangement "hot spot" in the Hymenoptera, Mol. Biol. Evol. 16, 298-309.

Dowton M., Belshaw R., Austin A.D., Quicke D.L.J. (2002) Simultaneous molecular and morphological analysis of braconid relationships (Insecta: Hymenoptera: Braconidae) indicates independent mt-tRNA gene inversions within a single wasp family, J. Mol. Evol. 54, 210-226.

Dowton M., Castro L.R., Campbell S.L., Bargon S.D., Austin A.D. (2003) Frequent mitochondrial gene rearrangements at the hymenopteran nad3-nad5 junction, J. Mol. Evol. 56, 517-526.

Engel M.S. (2001) Monophyly and extensive extinction of advanced eusocial bees: Insights from an unexpected Eocene diversity, Proc. Natl Acad. Sci. (USA) 98, 1661-1664

Estoup A., Solignac M., Harry M., Cornuet J.-M. (1993) Characterization of (GT)n and (CT)n microsatellites in two insect species: Apis mellifera and Bombus terrestris, Nucleic Acid Res. 21, 1427-1431.

Estoup A., Garnery L., Solignac M., Cornuet J.-M. (1995) Microsatellite variation in honey bee (Apis mellifera L.) populations: hierarchical genetic structure and test of the infinite allele and stepwise mutation models, Genetics 140, 679-695.

Estoup A., Solignac M., Cornuet J.-M., Goudet J., Scholl A. (1996) Genetic differentiation of continental and island populations of Bombus terrestris (Hymenoptera: Apidae) in Europe, Mol. Ecol. 5, 19-31.

Fernandes-Salomão T.M., Muro-Abad J.I., Campos L.A.D., Araújo E.F. (2002) Mitochondrial and nuclear DNA characterization in the Melipona species (Hymenoptera, Meliponini) by RFLP analysis, Hereditas 137, 229-233.

Fernandes-Salomão T.M., Rocha R.B., Campos L.A.O., Araújo E.F. (2005) The first internal transcribed spacer (ITS-1) of Melipona species (Hymenoptera, Apidae, Meliponini): characterization and phylogenetic analysis, Insectes Soc. $52,11-18$.

Francisco F.O. (2002) Diversidade genética de populações da abelha sem ferrão Plebeia remota: análise do DNA mitocondrial e microssatélites, MSc thesis, Instituto de Biociências, Universidade de São Paulo, São Paulo, SP [online] http://www.teses.usp.br/teses/disponiveis/41/41131/ tde-17062002-121701/ (accessed on 6 March 2006).

Francisco F.O., Silvestre D., Arias M.C. (2001) Mitochondrial DNA characterization of five species of Plebeia (Apidae: Meliponinae): RFLP and restriction maps, Apidologie 32, 323-332.

Franck P., Garnery L., Solignac M., Cornuet J.-M. (1998) The origin of west European subspecies of honeybees (Apis mellifera) new insights from mi- crosatellite and mitochondrial data, Evolution 52 1119-1134.

Franck P., Garnery L., Solignac M., Cornuet J.-M. (2000a) Molecular confirmation of a fourth lineage in honeybees from the Near East, Apidologie $31,167-180$.

Franck P., Garnery L., Celebrano G., Solignac M., Cornuet J.-M. (2000b) Hybrid origins of honeybees from Italy (Apis mellifera ligustica) and Sicily (A. m. sicula), Mol. Ecol. 9, 907-921.

Franck P., Garnery L., Loiseau A., Oldroyd B.P., Hepburn H.R., Celebrano G., Solignac M., Cornuet J.-M. (2001) Genetic diversity of the honeybee in Africa: microsatellite and mitochondrial data, Heredity $87,420-430$.

Franck P., Cameron E., Good G., Rasplus J.-Y., Oldroyd B.P. (2004) Nest architecture and genetic differentiation in a species complex of Australian stingless bees, Mol. Ecol. 13, 2317-2331.

Garnery L., Vautrin J.M., Cornuet J.-M., Solignac M. (1991) Phylogenetic relationships in the genus Apis inferred from mitochondrial DNA sequence data, Apidologie 2, 87-92.

Garnery L., Cornuet J.-M., Solignac M. (1992) Evolutionary history of the honey bee Apis mellifera inferred from mitochondrial DNA analysis, Mol. Ecol. 1, 145-154.

Garnery L., Mosshine E.H., Oldroyd B.P., Cornuet J.-M. (1995) Mitochondrial DNA variation in Moroccan and Spanish honey bee populations, Mol. Ecol. 4, 465-471.

Green C.L., Oldroyd B.P. (2002) Queen mating frequency and maternity of males in the stingless bee Trigona carbonaria Smith, Insectes Soc. 49, 196202.

Green C.L., Franck P., Oldroyd B.P. (2001) Characterization of microsatellite loci for Trigona carbonaria, a stingless bee endemic to Australia, Mol. Ecol. Notes 1, 89-92.

Hancock J.M. (1999) Microsatellites and other simple sequences: genomic context and mutational mechanisms, in: Goldstein D.B., Schlötterer C. (Eds.), Microsatellites: Evolution and applications, Oxford University Press, New York, pp. 1-9.

Hillis D.M., Moritz C., Mable B.K. (1996) Molecular Systematics, 2nd ed., Sinauer Associates, Massachusetts.

Kerr W.E., Zucchi R., Nakadaira J.T., Butolo J.F. (1962) Reproduction in the social bees (Hymenoptera, Apidae), J. N.Y. Entomol. Soc. 70, 265-276.

Koulianos S., Schmid-Hempel R., Roubik D.W., Schmid-Hempel P. (1999) Phylogenetic relationships within the corbiculate Apinae (Hymenoptera) and the evolution of eusociality, J. Evol. Biol. 12, 380-384. 
Levinson G., Gutman G.A. (1987) Slipped-strand mispairing: a major mechanism for DNA sequence evolution, Mol. Biol. Evol. 4, 203-221.

Li W. (1997) Molecular Evolution, Sinauer Associates, Inc., Sunderland, Massachusetts.

Lockhart P.J., Cameron S.A. (2001) Trees for bees, Trends Ecol. Evol. 16, 84-88.

Macey J.R., Larson A., Ananjeva N.B., Fang Z., Papenfuss T.J. (1997) Two novel gene orders and the role of light-strand replication in rearrangement of the vertebrate mitochondrial genome, Mol. Biol. Evol. 14, 91-104.

Meixner M.D., Sheppard W.S., Poklukar J. (1993) Asymmetrical distribution of a mitochondrial DNA polymorphism between 2 introgressing honey-bee subspecies, Apidologie 24, 147-153.

Meixner M.D., Arias M.C., Sheppard W.S. (2000) Mitochondrial DNA polymorphisms in honey bee subspecies from Kenya, Apidologie 31, 181-190.

Michener C.D. (1979) Biogeography of the bees, Ann. Missouri Bot. Gard. 66, 277-347.

Michener C.D. (2000) The Bees of the World, The Johns Hopkins University Press, Baltimore.

Moretto G., Arias M.C. (2005) Detection of mitochondrial DNA restriction site differences between the subspecies of Melipona quadrifasciata Lepeletier (Hymenoptera: Apidae: Meliponini), Neotrop. Entomol. 34, 381-385.

Moritz C., Hillis D.M. (1996) Molecular systematics: context and controversies, in: Hillis D.M., Moritz C., Mable B.K. (Eds.), Molecular Systematics, 2nd ed., Sinauer Associates, Massachusetts, pp. 1-13.

Oldroyd B.P., Smolenski A.J. Cornuet J.M., Crozier R.H. (1994) Anarchy in the beehive, Nature 371, 749 .

Paar J., Oldroyd B.P., Huettinger E., Kastberger G. (2004) Genetic structure of an Apis dorsata population: the significance of migration and colony aggregation, J. Hered. 95, 119-126.

Paxton R.J. (2000) Genetic structure of colonies and a male aggregation in the stingless bee Scaptotrigona postica, as revealed by microsatellite analysis, Insectes Soc. 47, 63-69.

Paxton R.J., Wei $\beta$ schuh N., Quezada-Euán J.J.G. (1999) Characterization of dinucleotide microsatellite loci for stingless bees, Mol. Ecol. 8, 93-99.

Paxton R.J., Bego L.R., Shah M.M., Mateus S. (2003) Low mating frequency of queens in the stingless bee Scaptotrigona postica and worker maternity of males, Behav. Ecol. Sociobiol. 53, 174-181.

Peters J.M., Queller D.C., Imperatriz-Fonseca V.L., Strassmann J.E. (1998) Microsatellite loci for stingless bees, Mol. Ecol. 7, 784-787.

Peters J.M., Queller D.C., Imperatriz-Fonseca V.L., Roubik D.W., Strassmann J.E. (1999) Mate num- ber, kin selection and social conflicts in stingless bees and honeybees, Proc. R. Soc. Lond. B 266, 379-384.

Ratnieks F.L.W. (1993) Egg-laying, egg-removal, and ovary development by workers in queenright honey bee colonies, Behav. Ecol. Sociobiol. 32, 191-198.

Rêgo M.M.C. (1992) Morfologia das estruturas genitais de machos na sistemática de Melipona, Naturalia edição especial, 73-78.

Schlötterer C., Wiehe T. (1999) Microsatellites, a neutral marker to infer selective sweeps, in: Goldstein D.B., Schlötterer C. (Eds.), Microsatellites: Evolution and applications, Oxford University Press, New York, pp. 238-248.

Schultz T.R., Engel M.S., Prentice M. (1999) Resolving conflict between morphological and molecular evidence for the origin of eusociality in the "corbiculate" bees (Hymenoptera: Apidae): a hypothesis-testing approach, Univ. Kans. Nat. Hist. Mus. Spec. Publ. 24,125-138.

Segura J.A.L. (2000) Highly polymorphic DNA markers in an Africanized honey bee population in Costa Rica, Genet. Mol. Biol. 23, 317-322.

Shao Z.-Y., Mao H.-X., Fu W.-J., Ono M., Wang D.-S., Bonizzoni M., Zhang Y.-P. (2004) Genetic structure of Asian populations of Bombus ignitus (Hymenoptera: Apidae), J. Hered. 95, 46-52.

Sheppard W.S., Smith D.R. (2000) Identification of African-derived bees in the Americas: A survey of methods, Ann. Entomol. Soc. Am. 93, 159-176.

Sheppard W.S., Meixner M.D. (2003) Apis mellifera pomonella, a new honey bee subspecies from Central Asia, Apidologie 34, 367-375.

Sihanuntavong D., Sittipraneed S., Klinbunga S. (1999) Mitochondrial DNA diversity and population structure of the honey bee, Apis cerana, in Thailand, J. Apic. Res. 38, 211-219.

Silvestre D. (2002) Seqüenciamento e análise do genoma mitocondrial de Melipona bicolor (Hymenoptera, Apidae, Meliponini), MSc thesis, Instituto de Biociências, Universidade de São Paulo, São Paulo, SP [online] http://www.teses.usp.br/teses/disponiveis/41/41131/ tde-06052002-110339/ (accessed on 6 March 2006).

Silvestre D., Arias M.C. (2006) Mitochondrial tRNA gene translocations in highly eusocial bees, Gen. Mol. Biol. (in press).

Silvestre D., Francisco F.O., Weinlich R., Arias M.C. (2002) A scientific note on mtDNA gene order rearrangements among highly eusocial bees (Hymenoptera, Apidae), Apidologie 33, 355-356.

Simon C., Frati F., Beckenbach A., Crespi B., Liu H., Flook P. (1994) Evolution, weighting, and phylogenetic utility of mitochondrial gene sequences and a compilation of conserved polymerase chain reaction primers, Ann. Entomol. Soc. Am. 87, 651-701. 
Smith D.R. (1991) Mitochondrial DNA and honey bee biogeography, in: Smith D.R. (Ed.), Diversity in the genus Apis, Westview Press, Colorado, USA, pp. 131-176.

Smith D.R., Villafuerte L., Otis G., Palmer M.R. (2000) Biogeography of Apis cerana F. and A. nigrocincta Smith: insights from mtDNA studies, Apidologie 31, 265-279.

Sušnik S., Kozmus P., Poklukar J., Megliè V. (2004) Molecular characterization of indigenous Apis mellifera carnica in Slovenia, Apidologie 35, 623-636.

Tanaka H., Roubik D.W., Kato M., Liew F., Gunsalam G. (2001) Phylogenetic position of Apis nuluensis of northern Borneo and phylogeography of $A$. cerana as inferred from mitochondrial DNA sequences, Insectes Soc. 48, 44-51.

Tóth E., Queller D.C., Imperatriz-Fonseca V.L., Strassmann J.E. (2002a) Genetic and behavioral conflict over male production between workers and queens in the stingless bee Paratrigona subnuda, Behav. Ecol. Sociobiol. 53, 1-8.

Tóth E., Strassmann J.E., Nogueira-Neto P., Imperatriz-Fonseca V.L., Queller D.C. (2002b) Male production in stingless bees: variable outcomes of queen-worker conflict, Mol. Ecol. 11, 2661-2667.

Tóth E., Strassmann J.E., Imperatriz-Fonseca V.L.,
Queller D.C. (2003) Queens, not workers, produce males in the stingless bee Schwarziana quadripunctata quadripunctata, Anim. Behav. 66, 359-368.

Tóth E., Queller D.C., Dollin A., Strassmann J.E. (2004) Conflict over male parentage in stingless bees, Insectes Soc. 51, 1-11.

Vawter L., Brown W.M. (1986) Nuclear and mitochondrial DNA comparisons reveal extreme rate variation in the molecular clock, Science 234, 194-196.

Weinlich R., Francisco F.O., Arias M.C. (2004) Mitochondrial DNA restriction and genomic maps of seven species of Melipona (Apidae: Meliponini), Apidologie 35, 365-370.

Wille A. (1983) Biology of the stingless bees, Annu. Rev. Entomol. 28, 41-64.

Wille A., Orozco E. (1975) Observations on the founding of a new colony by Trigona cupira (Hymenoptera: Apidae) in Costa Rica, Rev. Biol. Trop. 22, 253-287.

Winston M.L., Michener C.D. (1977) Dual origin of highly social behavior among bees, Proc. Natl Acad. Sci. (USA) 74, 1135-1137.

Wolstenholme D.R. (1992) Animal mitochondrial DNA: structure and evolution, in: Wolstenholme D.R., Jeon K.W. (Eds.), Mitochondrial Genomes, Academic Press, San Diego, pp. 173-216. 